(Forthcoming, 2020) The contradictory politics of the right to travel: mobilities, borders and tourism. Mobilities. Accepted 26.11.19. DOI: 10.1080/17450101.2020.1723251.

\title{
The Contradictory Politics of the Right to Travel: Mobilities, Borders and Tourism
}

\author{
Raoul V. Bianchi \\ Reader in International Tourism and Development \\ Institute for Hospitality and Tourism \\ $\&$ \\ Centre for the Study of States, Markets and People \\ School of Business and Law \\ University of East London \\ London, UK
}

Marcus L. Stephenson

Dean \& Professor of Tourism and Hospitality Management

School of Hospitality

Sunway University

Selangor Darul Ehsan, Malaysia

\author{
Kevin Hannam \\ Professor of Tourism \& \\ Dean, Faculty of International Tourism and Management \\ City University of Macau \\ Macau, People's Republic of China
}




\title{
The Contradictory Politics of the Right to Travel: Mobilities, Borders and Tourism
}

\begin{abstract}
The freedom of movement and right to travel are intrinsic to the growth of international tourism. Notwithstanding the inchoate nature of the right to tourism, the entitlement to travel and to pursue tourism without hindrance is firmly established in advanced capitalist societies. Moreover, the right to tourism has been recently enshrined in the 2017 United Nations World Tourism Organisation (UNWTO) Framework Convention on Tourism Ethics. Tourists' ease of mobility contrasts starkly with the movements of less privileged forms of mobility that may be variously constrained by racism, xenophobia and restrictive border controls. This paper contends that rather than a mere reflection of accumulated political rights (citizenship), such unequal and differentiated mobilities are conditioned by a complex assemblage of discursive frameworks and structural forces that are played out in specific historical-geographic contexts. Accordingly, we argue that the rights associated with global tourism must be analysed in the context of the contradictory politics of global mobility, or indeed in terms of the "mobility crisis'. This 'crisis' is one that is rooted in and shaped by the cumulative legacy of past colonial orders, global capitalism and geopolitical realignments, in addition to multi-scalar systems of governance through which borders are constituted, managed and policed.
\end{abstract}

Key words: tourism, borders, geopolitics, securitization, mobilities, rights. 


\section{Introduction}

To allow a man [sic] to travel is to allow him to do something that one has no right to deny: it is a social injustice. (Peuchet, 1790, cited in Torpey 2000, 25)

Travel writer Kassabova (2017) rightly identifies the seductive nature of borders which hold an enduring fascination for tourists (Timothy 2000). However, the right and ability of humans to travel freely and without hindrance across international borders are increasingly subject to intense political scrutiny and even wider public debate. Profound inequalities mark the differential mobility empowerments of tourists and 'legitimate' travellers on the one hand and those lacking the "right credentials for travel" on the other, notably migrants, refugees and asylum seekers (Kaur \& Hutnyk 1999, 3). Nonetheless, the socio-political and economic forces governing the differentiated and unequal movements of people are not a mere function of disparities in the material wealth of nations. While divisions in the global political economy remain significant, differentiated and unequal patterns of cross-border travel are constituted by mutually reinforcing strategies of multi-level border governance and discourses of inclusion/exclusion; through which the policing and ordering of "differential mobility empowerments" are normalized and institutionalized (Tesfahuney 1998)

This paper presents a critical reflection on how tourism operates through and further shapes multi-dimensional relations of power at multiple scales through which it becomes implicated in the co-constitution of bordering processes. Indeed, Richardson $(2013,1)$ has noted that "it is difficult to conceive of mobilities without confronting the ways in which mobilities are constrained and regulated by borders and bordering practices." In this paper we challenge the commonly held view of tourism as a benign form of mobility whose contribution to peace, prosperity and sustainable development is often read as 'undeniable', to interrogate how tourism intersects with differentiated flows of people, commodities, capital and technologies and is furthermore constitutive of coercive regimes of mobility and border governance.

Of the many increasingly fortified borders worldwide demarcating the boundaries between those who are entitled to "the collective fiction of universal rights" and those who are not (Calori 2015), the border between the United States and Mexico together with Europe's militarised maritime frontier spanning the Mediterranean, are amongst the world's deadliest (Jones 2016). ${ }^{1}$ The current political turmoil that partly resulted from the recent upsurge in 
refugees and migrant movement, underpins the widespread consensus amongst rich states regarding the 'need' to reduce historically high levels of immigration (Prince 2010). The discursive framing of certain mobilities as 'problematic' in the light of such unevenly distributed mobility rights raises serious questions, particularly when juxtaposed against the political imperative to ensure the continued growth and expansion of tourism espoused by governments, industry and international institutions (Gascón 2019). Nevertheless, while the rights equated with participation in tourism are envisaged as akin to human rights (see UNWTO 2017), in practice they remain unevenly distributed, ambiguous and contested.

During the early nineties some analysts offered an account of the emerging global order that envisaged a world of increasingly integrated markets, frictionless trade and the free movement of goods, services and people driven by the globalising logics of capitalist competition (Ohmae 1990). Many were nevertheless sceptical of the implied inevitability of the state's demise (Hirst \& Thompson 1996), as well as the degree to which borders were being dissolved (O'Tuathail 1999). However, the ideological and rhetorical force of mobility and transnational connectivity has taken an even more forceful turn in the new millennium. The past two decades have witnessed a resurgence of state power and attempts to enclose territories, (re)impose borders and restrict the movement of certain categories of people. Borders are "used and constructed and opened and closed depending on who crosses them and on how contentious they become in political debates" (Scuzzarello \& Kinnvall 2013, 93). As this paper will argue, tourism operates within the context of the contradictory forces associated with accelerated mobilities and transnational flows on the one hand and the forces of enclosure and disenfranchisement on the other, which are furthermore shaped through processes of global capitalist expansion and the political organization of space.

The analysis presented in this paper argues that the uneven and differentiated mobility rights associated with global travel and tourism must be analysed in the context of the contradictory politics of global mobility or 'mobility crisis' and its multiplex intersections with bordering processes. In her formulation of the concept of mobility justice Mimi Sheller (2018) posits the 'mobility crisis' as one which is constituted out of inter-connected crises of the environment/climate, urbanization and mass migration/refugee crisis. We would extend this logic further to argue that, contrary to conventional readings of crisis as a temporary malfunctioning of the orderly logics of our political and economic system, contemporary bordering practices and securitization strategies are intrinsic to an emerging model of increasingly authoritarian capitalism designed to protect and extend the frontiers of profit- 
making centred on increasingly predatory modes of capital accumulation (see Sassen 2014). The mobility crisis is one that is rooted in and shaped by the extractive logics of colonialism and post-colonial global capitalism, geopolitical realignments and multi-scalar systems of governance through which borders are constituted, managed and policed. Above all it is indicative of deep structural contradictions in a mutating model of contemporary global capitalism and the multiplex security and border arrangements needed to manage and regulate the movement of the mobile poor and sustain conditions for the accumulation of capital.

The paper is structured into three parts. First, by way of a critique of the realist and 'territorialist' epistemologies that frame studies of tourism politics, the paper commences with a concise review of recent critical literature on mobilities, geopolitics and the transformations of border governance in neoliberal societies. Second, the focus then shifts onto the transformation of the state's monopoly on the regulation of cross-border travel in the context of an emerging global regime of mobility rights and regulation. Here the paper highlights how important tensions between the freedom of movement and travel on the one hand and the right to tourism and holiday-making on the other, have transpired in the context of the unresolved relationship between national and inchoate global notions of citizenship. Third, the paper examines the proliferation of complex modes of bordering and securitization of the travel and tourism industries through the lens of biopolitics and the diffuse landscapes of power that govern mobilities. In the conclusions, the authors reflect on the nuances and entanglements that emerge at the intersection of tourist and other less favoured mobilities. While challenging simplified dichotomies of 'empowered tourists' and 'disempowered others', the paper contends that the differentiated and uneven geographies of (im)mobility that are currently unfolding and in which tourism plays a key role must be understood in the context of the contradictory politics of global mobilities.

\section{Mobilities, borders and geopolitics}

\section{Border governance and rescaling state power}

In recent years, the "mobilities paradigm" has brought attention to the myriad ways in which contemporary travel and "differential mobility empowerments" "reflect structures and hierarchies of power" (Hannam, Sheller \& Urry 2006, 3), involving a spectrum of voluntary to involuntary or coerced mobilities. Accordingly, Salazar \& Schiller $(2013,189)$ argue that the 
current global order is beset by "different intersecting regimes of mobility" in which the movements of certain categories of people are simultaneously "normalised" while others" movements are "criminalised". While mobility often signifies access to citizenship rights (Cresswell 2013), Franquesa $(2011,8)$ warns against the inclination to associate mobility with power and a cosmopolitan disposition as this reflects a tendency to collapse "multiple uneven social categories into a single difference”. Equally, Adey (2006) observes that mobility and immobility do not exist as a fixed dichotomy but are interdependent and mutually constructed out of multiple intersecting social relations. Not only are such social relations enacted through complex and over-lapping mobilities, mobility theorists often see power itself as "relational, mobile and never complete" (Baerenholdt 2013, 23).

Through the concept of mobility justice Sheller $(2018,14)$ links the "governance and control of movement" to multiple inter-connected struggles for environmental, economic and social justice at multiple scales. Accordingly, it is not sufficient to highlight the existence of discrepant mobilities and simply argue for greater mobility freedoms or to ensure the universal implantation of existing (legal) mobility rights. Rather it requires closer inspection of the interrelationship between uneven and differentiated mobilities and the forces governing the use and organisation of space. There are clear echoes here of Sassen's $(2104,5)$ concept of expulsions that she deploys in seeking to highlight the 'deeper systemic dynamics' characteristic of a new phase of predatory capitalist expansion and value extraction. Therefore, by drawing upon the concepts of mobility justice and expulsions the analysis presented here brings together themes of border governance, bio-politics, securitization and migration to interrogate and identify the systemic logics and tendencies linking the (new) lines of fracture and modes of power that shape and characterise contemporary tourism mobilities.

In spite of the pervasive "ideology of perpetual movement" that increasingly defines the character of advanced post-industrial societies (Doumayru, 2010, 14), mobilities remain structured by the "fixity" of "borders, institutions and territories of nation-states" (Favell, 2001, 391-2). The power of the state, international relations and variable permeability of borders influence and determine the territorial scope and composition of travel. This is particularly so where geopolitical tensions result in the citizens of one or a collection of countries being denied entry by another (Bianchi \& Stephenson, 2014, 100-107). In contrast, borders themselves may “invoke a unique type of fascination" for tourists (Timothy 2000, 57). Accordingly, crossborder tourism initiatives established in borderland regions have attempted to enhance the 
cooperative management of resources that straddle political frontiers and overcome the spatial discontinuities in adjacent borderland economies (Blasco, Guia \& Prats 2014; Hampton 2010; Guereno-Omil, Hannam \& Alzua-Sorzabal 2014).

Despite resurgent nationalist ideologies the management of border security is an area in which a significant degree of cooperation between states has significantly increased (Geddes, 2000). As far as international tourism agencies are concerned, borders are viewed as impediments to travel. Hence pro-tourism bodies argue that restrictive borders regimes (for 'tourists') should be relaxed or eliminated altogether (World Travel \& Tourism Council 2017). Realist understandings of geopolitics and security have framed the study of tourism and international relations, focussing on how the global political landscape comprises different states pursuing their national interests through a combination of war, diplomacy and political alliances (see Telfer \& Hashimoto 2015, 409-411). Borders are largely construed as fixed markers delineating the geographical boundaries separating the sovereign-territorial authority of states (Timothy 2001). However, the relationship between tourism and restrictive border practices is not simply a function of increased state power and the attendant territorialization of sovereignty. Rather, as Hazbun $(2008,80)$ demonstrates in relation to the role of tourism in shaping the new political landscape of the Middle East during the 1990s, tourism is a "constituent element" of geopolitical transformations in the region. Further to being harnessed to the expansionist designs of states (Hannam 2013; Rowen 2014); tourism produces a range of multi-scalar intersections with geopolitical discourses and practices (Enloe 2014; Gillen and Mostafanezhad 2019; Rowen 2016). Hotels too are complex and highly symbolic geopolitical sites that are drawn into wider conflicts, tensions and encounters (Fregonese \& Ramadan 2015).

Bauder $(2012-13,1)$ describes borders as the "primary site where contemporary inequalities and injustices, hegemony and repression are created and reproduced". However, while states retain considerable power and authority over their borders and who crosses them, critical geopolitics theorists have challenged the "territorialist epistemology" inherent in state-centric conceptions of borders as fixed demarcations between sovereign territorial nation-states (Vaughn-Williams, 2012, 50). Thus, argues Rumford (2006), borders constitute a mobile, diffuse and complex assemblage of multi-scalar technologies of control and coercion as the authority of states increasingly intersects with new, multi-level scales of governance characteristic of an authoritarian neoliberalism. Increasingly states have sought to reterritorialize powers in response to the surrender of sovereignty to financial markets and the 
rescaling of powers to supra-national institutions. However, intensified inter-penetration of corporate and state powers characterises neoliberal modes of border governance. Border management procedures are thus being re-scaled and dispersed throughout myriad collaborating authorities.

The rescaling of state power also signals a substantial shift in the nature and function of border controls. No longer do borders merely serve to delimit the geographic boundaries of sovereign political authority and distinctive economic systems, they have become instruments for the policing of "dangerous mobilities" (Walters 2006, 199). This shift has taken place in tandem with the rise of sophisticated technologies and diverse practices of border control, from "preemptive" strategies designed to identify threats from 'risky' subjects before they materialise to the "out-sourcing" of borders (Vaughn-Williams 2012, 22-24). States have long enlisted private companies to oversee cross-border movement, from steamship companies in the nineteenth century (Torpey 2000, 10) to deportation flights in the early 2000s (Verkaik 2007). The contemporary governance of borders has seen the application of tracking technologies (eg., drones and data-mining software) in tandem with the rescaling and out-sourcing of border governance to a series of "coexisting networks and partnerships at diverse spatial scales" on an altogether different scale (Prokkola 2012, 1321). Such practices have brought together different levels and degrees of state power, national security agencies, corporations and private militias (see Robin 2017). ${ }^{2}$

The degree of permeability of borders is influenced by a constantly shifting matrix of regulatory frameworks governing cross-border movement that are in turn influenced by the status of diplomatic relations between states, trade agreements, security imperatives and biosecurity hazards (Coles \& Hall, 2011). The way in which borders are experienced depends on the identity of those seeking to cross them. As Burrell $(2008,353)$ has written, "the physical practice of journeying and border crossing is not an empty act, suspended in space and time between two realities, but is a highly materialised and emotional undertaking, and a real, tangible space in its own right." Even where a traveler might be in possession of the appropriate documentation, the 'legitimate' status of the traveller is often not determined until he/she attempts to cross the border (Torabian \& Miller 2017). They could remain in a state of legal limbo, where "one may claim no rights but is still subject to the law" (Salter 2006, 169). Upon or indeed prior to arrival at the border, while applying for necessary visas (see Dheghan 2017), racialized and national identities are instantiated and individuals are deemed rightfully able to 
enter another state or not (Stephenson 2006). Not only are attempted border crossings in the absence of the necessary credentials labelled as 'illegal', the criminality of those seeking to 'illegally' cross international borders can be amplified by people's desperate need to contract criminal gangs and traffickers to do so (Hardy 2000, 14).

\section{Neoliberalism and the governance of borders}

The central preoccupation of neoliberal governance is to manage the contradictions that arise from state strategies to ensure the compatibility of territorial security with a minimum of hindrance to markets and the free movement of capital (Ó Tuathail 1999). Some degree of labour mobility is needed to overcome skill shortages or indeed, deployed as means to undercut local collective bargaining regulations as illustrated in various disputes over the EU's 'Posted Workers Directive' (see Labour \& European Law Review 2008). However, in spite of evidence suggesting that allowing migrants to move freely would increase global GDP by between 67 and 147 per cent (Eaton 2017), under the current model of neoliberal governance human needs have become secondary to those of corporate profitability and security (see Moore 2012). In this regard, the mobility of the world's impoverished peoples is significantly restricted including those denied refugee status and increasingly, surplus to the requirements of capital (Sassen 2014, 10). Meanwhile the mobility of tourists is zealously encouraged on the grounds of tourism's innate capacity to stimulate economic growth and generate prosperity (UNWTO 2019).

Since 2001, a number of Caribbean states have pursued policies of trade liberalization, economic deregulation and luxury resort development, even suspending passport checks for disembarking cruise passengers. This is to allow for greater ease of capital and tourist flows, while its citizens are subject to increased surveillance and screening of mobilities under the auspices of the United States' Third Border Initiative (Sheller 2010, 274). The ban on travel to the US from seven Muslim states (Iraq, Iran, Libya, Somalia, Sudan, Syria and Yemen), initially imposed by the US President Donald Trump in early 2017 (Walters, Helmore \& Dehghan 2017), illustrates the extent to which some states will go to restrict legitimate forms of mobility, particularly those states driven by nationalist-populist interests. This can happen irrespective of the fact that such restrictions can fuel prejudice in society and run contrary to the economic interests of the tourism industries (see Hyde, 2016; Ting, 2017). Where states succumb to populist pressures for a greater say in the democratic process, as in the case of the 
UK's 2016 referendum on membership of the European Union, the result may contradict the interests of the corporate tourism industries (see Steiner 2017).

\section{The freedom of movement and the right to travel}

\section{The evolution and implication of passports}

Prior to the emergence of the modern nation-state in the early nineteenth century, the right to leave and enter different sovereign territories remained relatively unhindered. Historically, the power to authorise movements within and between sovereign territories rested primarily with feudal lords, monarchs and the rulers of principalities, city-states and sultanates who sought to regulate and tax the movement of people for the purposes of extracting revenues (Torpey 2000). The requirement to carry a passport for the purposes of international travel came about in the context of efforts by emerging sovereign-territorial states to monopolise the "legitimate means of movement" (Torpey 2000, 7). The right to travel without passports remained possible throughout many parts of the world, particularly if the person was a "European traveller of respectable appearance" (Lloyd 2003, 116). It was not until the outbreak of the First World War that states began to introduce stricter controls on cross-border movement, including the requirement for travellers to carry passports and where necessary valid visas. This was often justified on the grounds of weeding out enemies of the state, when citizens deemed a threat to “national security and public order" would have their passports withheld (Dowty 1987, 113).

By 1925, following a League of Nations conference in 1920 to consider standardising the international passport, possession of a valid passport and in certain cases an exit visa had become a legal requirement for travel in forty out of forty-three countries surveyed by the League, with the exception of the United States (not a member) and Canada (Dowty 1987, 62). However, while the right to a passport is often synonymous with the right to travel, it by no means guarantees the right of citizens to cross international borders (Torpey 2000, 161). During the inter-war period, the growing volume of stateless persons in Eastern Europe prompted the League of Nations to devise the Nansen Passport, the first supranational travel document of its kind (Torpey 2000, 127-129). Despite this initiative and attempts by US peace activist Garry Davis to devise a "world passport" (see Davis 1961), the legitimacy and authority of the nationstate as the legitimate arbiter of cross-border movement remained largely unchallenged. 
Following the Second World War a "moral ethos of rights" began to lay the foundations for a transnational legal architecture of human rights (Faist 2009, 9), aiming to protect individuals from the arbitrary exercise of state power and based on a framework of ethical rights granted to all humans by virtue of their "common humanity" (Delanty 2000, 69). Set against the backdrop of the Cold War, the rapid growth of tourism came to be seen as a symbol of freedom and marker of citizenship, while the right to travel was subsequently established as a universal human right (Bianchi \& Stephenson 2013, 2014). The right to the freedom of movement was clearly set out in Article 13 of the Universal Declaration of Human Rights (1948), stipulating that "everyone has the right to leave any country including his [sic] own - and to return to his [sic] country" (United Nations 1948). Following that, in 1966 the International Covenant on Economic, Social and Cultural Rights (ICESCR) set out the right to leisure and holidays within a legally binding political framework (Breakey \& Breakey 2013, 741).

By the end of the twentieth century participation in particular forms of tourist activities, framed by ethical and moral concerns (e.g., volunteer tourism), was becoming strongly associated with the propagation of global citizenship (Butcher 2017). Although the moral, political and even legal foundations of the "right to tourism" remain ambiguous and contested (see Breakey \& Breakey 2013), the idea that "tourists must be allowed freedom of movement in the destination countries" enjoys a broad consensus (Nkyi and Hashimoto 2015, 397). Indeed, any hindrance to the freedom of travel, particularly where it is the result of labour disputes, often provokes public protest (see Evening Standard 2011).

Contrary to previous historical periods in which travel rights were invoked by domestic citizens as a means of challenging oppressive rule (for example in the former German Democratic Republic), a profound ideological shift has taken place in which tourism has become a "takenfor-granted" pursuit to which many citizens in advanced post-industrial societies feel entitled (Urry 2013, 62). Furthermore, the Global Code of Ethics for Tourism (WTO 1999) and recent Framework Convention on Tourism Ethics (UNWTO, 2017) blurs fundamental ethico-legal distinctions between the freedom of movement and right to travel on the one hand and the right to tourism on the other. The "right to tourism and freedom of tourist movements" are furthermore construed within the organising framework of "private enterprise and free trade" (WTO 1999). 
The sustained annual average growth in international tourist arrivals is a consequence of the cheapening of mass travel through intense competition between travel providers and growth of online booking platforms. Equally, growing demand for foreign travel amongst Asia's new middle classes and the impressive growth of incomes at the upper end of the global wealth pyramid are driving demand for luxury travel services (see Dykins 2016; Peltier 2015). Where once tourism was interpreted as part of citizens" "civic responsibilities" (WTO, 1980, Para. 22), the freedom to pursue tourism in neoliberal societies is in many ways concomitant with a 'duty' to help lubricate the wheels of the global economy and boost destination prosperity.

The idea that international tourism represents a largely benign form of cross-border movement, premised upon consensual trade ties between market economies, exerts a powerful influence on government thinking worldwide, supported by the UNWTO and such major lobby groups as the World Travel and Tourism Council (WTTC). However, this view helps to blur if not efface altogether important distinctions between commerce and trade on the one hand and a democratic politics of free movement on the other. While the right to travel and the liberty of movement are enshrined in the UNDHR and the protection of such rights is set out in the ICESCR, tourism is unique amongst industries in proclaiming its elevation to a human right (Higgins-Desbiolles 2007). Accordingly, any restrictions placed on the tourism, even for progressive reasons such as mitigating climate change, may be seen as an elitist attempt to curtail the freedom of the masses to enjoy holiday-making (Butcher and Smith 2019). In

addition, tourism is the only industry that warrants its own specialist UN agency, bestowing upon it a political status not enjoyed by other areas of commerce and trade (Ferguson 2007). Notwithstanding modest appeals to sustainability tourism is supported by a global authority dedicated to its continuous growth and expansion, while forms of mobility that are deemed by the authorities to be less desirable are increasingly regulated, controlled and restricted, if not criminalised altogether.

\section{Visa restrictions and the politics of bordering}

The WTTC continues to regard restrictive visa policies as a major hindrance to the growth and prosperity of international tourism (WTTC 2017). These efforts are mirrored in the competitive struggle between governments worldwide to liberalize visa regimes to attract increased volumes of high-spending Chinese tourists (The National 2016; Watt 2013), a mere five per cent of whom possess passports (Fernández Rubio 2015). Conventionally speaking, "the richer 
the country of origin, the more visa-free travel options its citizens enjoy" and "the more democratic a country is, the more countries waive the visa requirements for its citizens" (Mau 2010, 348). In 2016, for example, the citizens of Timor-Leste were able to travel without applying for a visa prior to departure to 86 countries compared to only 49 countries in 2015 (Henley \& Partners 2015, 2016). The European Parliament viewed this initiative as representing "a culmination of deepening relations between the European Union and the Democratic Republic of Timor-Leste", especially Timor-Leste's post-independence drive towards "democratic stabilisation" and the strengthening of "economic relations" (Government of Timor-Leste 2015). In contrast, those citizens who face the highest refusal of visa applications in 2007 came from seven countries ranked as undemocratic and poor: Armenia, Guyana, Laos, Mongolia, Senegal, Uzbekistan and Yemen (Mau 2010, 352). Despite (or perhaps as a result of) the difficulties encountered by African citizens travelling to the West, there are moves by the African Union to develop an African passport to encourage the free movement of African citizens and bolster tourism and regional economic development across the continent (African Development Bank 2016).

Nearly 30 years since the removal of one of the most symbolic of barriers to the freedom of movement, the Berlin Wall, a world of seamless cross-border travel has only materialized for a privileged minority of the world's citizens. A combination of factors conspired to bring about the expansion of borders and proliferation of restrictive bordering practices, not just in authoritarian states but also among liberal capitalist democracies - where, ironically, the right to tourism itself has become an integral component of citizenship. Divergent experiences and variable pathways of mobility nevertheless resist binary distinctions between the mobile and immobile. The continued and growing socio-economic inequalities are not the sole determinants for variable and unequal movements of people across borders. The material constraints to international travel and the pursuit of tourism are intersected and shaped by multi-level border governance strategies, where people's right to cross borders and enter and move throughout sovereign territories are selectively authorized and legitimated in relation to racialized and other subjectivities. 


\section{Securitized travel and the biopolitics of mobility}

\section{Border governance, bio-power and biometric borders}

Security delays at a number of European airports during the summer of 2017, associated with the increased threat of terrorist attacks and strikes by immigration officials, were bizarrely interpreted by sections of the UK tabloid media as "punishment" for the recent vote to leave the EU (McKinstry 2017). The discursive reinforcement of differential mobility entitlements was further evidenced by the xenophobic response to the long delays at European airports, whereby "law-abiding British passengers" going about (in their view) the 'rightful business' of holiday-making were contrasted with the "vast influx of non-European migrants" who are often "welcomed with no questions asked" (McKinstry 2017). Here we see a paradox of modern travel at work: while citizens of wealthy states want their borders to be strongly enforced and securitized they simultaneously desire a minimum of hindrances to their own mobility when travelling. Fueled by fears of an increasingly diffuse and mobile terrorist threat and media panics surrounding the current political turmoil concerning refugees and migrants, states are reasserting their authority over borders and expanding the scope of control over the crossborder movements of 'risky', 'suspect' or 'undesirable' travelers. These moves encompass the construction of physical security barriers and the implementation of a range of technologically advanced surveillance systems and restrictive bordering practices to hinder or prevent crossborder movements. During the period from 2001 to 2012, thirty barriers and walls were built compared to the 19 constructed between 1945 and 1991 (which include the Berlin Wall). A further seven were erected during the post-Cold War period from 1991 to 2001 (Vallet \& David 2012, 113). These changes signal a deep structural and ideological shift in the governance of bordering processes. As Andreas $(2000,2)$ has argued,

The celebrated debordering of the state ... is far more selective than the inflated rhetoric of globalization would suggest. Debordering is being accompanied in many places by a partial rebordering in the form of enhanced policing. Even as many borders have been demilitarized in the traditional realm of national security, as well as economically liberalized to facilitate commercial exchange, they are also now more criminalized to deter those who are perceived as trespassers. Thus it may be more accurate to say that the importance of territoriality is shifting rather than simply diminishing. 
While the power of the state continues to drive the roll out of new securitization technologies, equally, the enactment of such technologies relies on the complicity of the ordinary citizen who increasingly 'participates' in their own surveillance (Lyon 2004, 37). The self-regulating surveillance of everyday life has been magnified by a climate of perpetual insecurity, together with the increased use of social media and the "enchantment" associated with mobile technologies (smart phones) and processes (loyalty schemes) through which contemporary data-mining and surveillance are enacted (see Weaver 2008, 3). The role played by the proliferation of mobile and other digital technologies can be understood as a form of 'biopower' (Foucault 1978), through which the complicity of citizens in the ordering of social life is enacted through disciplinary conformity to the securitized norms governing travel and the seductive power of mass consumption. The scope of 'bio-power' is institutionalised through the expanding "biopolitical economy of informational capitalism" as economic value is increasingly driven by the monetisation of personal data (Cohen cited in Powles 2015). Moreover, the technologies deployed in surveillance and border security (e.g. optical scanning, biometric IDs and data-mining) emerge out of the increasingly close cooperation between the state and private corporations that are "involved in every aspect of the national security state" (Engelhardt 2015, 6). Such is the scope of inter-penetration between corporate business and state border management agencies that by 2022 it is estimated that the global market for border security will be worth $€ 50$ billion (Delle Femmine 2017).

For Amoore $(2006,348)$, the biometric border is no longer fixed but mobile, whereby technologies encoded within the mobile subjects themselves make it very difficult to evade the tentacles of state power. Together with the increased use of biometric identifiers in passports and ID cards - already mandatory in the US since 2002 - the January 2015 attacks on Charlie Hebdo journalists in Paris provoked calls by the European Commissioner for Migration, Home Affairs and Citizenship to fast-track the introduction of the long-delayed Passenger Name Records' (PNR) system throughout the EU. Following the 9/11 attacks in the United States, the Department of Homeland Security demanded that all flights from the EU to the US collect and handover a range of passenger information to enable US security services to profile and identify potential terrorists. Although objections from the European Court of Justice and the European Parliament delayed the implementation over concerns related to the right to privacy (Statewatch 2015), the EU adopted a new PNR directive in April 2016 (Council of the European Union 2016). 


\section{Border practices and discriminatory profiling}

The discriminatory logics of bordering practices is further reinforced by the linguistic framing of certain categories of mobility as 'desirable' (tourists, academics, businesspeople, diplomats, and sometimes, journalists) in contrast to the de-legitimisation of migrant and other 'undesirable' mobilities. These logics do not operate along a simple tourist/migrant binary rather they are underscored by the socio-political differentiation between the "good citizen" and the "failed citizen" (Anderson 2014). Not only is this normative categorisation inscribed and reproduced through anti-immigration discourses, the failed citizen can encompass both natives (feckless, welfare-dependent citizens) and foreigners (migrants, refugees and terrorists). What unites them is that they are both positioned outside of what Anderson $(2014,2)$ terms the "community of value", where neither are deemed to make a positive contribution to society or the economy. There is however an important distinction between each category indicating how the bio-political ordering of draconian bordering practices implicates and pits the 'native-born' citizen against the mobile 'outsider'. Whereas the native-born "failed citizen" is deemed "not mobile enough", the foreign "non-citizen" is seen as "too mobile" (Anderson 2014, 9). The shifting coordinates of discriminating bordering discourses has been amply illustrated by increased hostility to citizens of East European EU member states in other parts of the European Union, notably in the lead up to the June 2016 'Brexit' referendum in the UK.

Unceasing vigilance towards "suspect communities" (Hickman et al. 2011), together with discriminatory profiling of certain minority and ethnic communities, particularly those of ArabMiddle Eastern descent, reinforces discrimination and social division amongst an anxious public. Accordingly, a constant state of a "permanxiety" has been induced amongst Muslim travellers and other minority travellers who constantly fear being turned back or detained by border agents (Ali 2017). A continual cycle of media-driven discourses of insecurity further amplified on social media reinforces a climate of perpetual fear while technologized border security systems profile, sort and separate those judged to be of significant risk. For instance, two Muslim women were removed from a JetBlue plane heading from Boston to Los Angeles, after it was alleged that the pair were staring at a flight attendant (Khan 2016). Another illustration concerns a Muslim family of 11 who had their holiday to Disneyland terminated without further explanation by Department of the US Homeland Security officials at London's Gatwick airport, despite having been pre-authorised to travel (Addley \& Holpuch 2015). This case bears witness to the 'off-shoring' of US bordering practices, whereby visas can be revoked 
by officials working under the auspices of the Department of Homeland Security stationed at UK ports of entry/exit since 2011 (Oltermann 2014).

In the wake of the Paris attacks and subsequent terrorist incidents across Europe in the first half of 2016, there have been strident demands by neo-conservative and populist politicians on both sides of the Atlantic for the closure of borders as a means of combatting the threat of terrorism. Following the Charlie Hebdo attacks Marine Le Pen, Leader of France's National Front, requested that President Hollande suspend the Schengen Agreement to control the country's borders (Guardian 2015). The state of emergency imposed in response to the attacks remained in place until November 2017, despite ongoing concerns regarding the infringement of civil liberties (Serhan 2017). Even prior to these events, a US Republican presidential candidate and Governor of New Jersey proposed countering 'illegal' immigration via the use of tracking devices on all foreign tourists entering the US, similar to the way in which FEDEX tracks its parcels (Reuters 2015).

Bordering processes increasingly align with and accentuate discriminatory immigration policies, as illustrated on 20 January 2017 by the travel ban imposed by US President Trump on individuals from seven Muslim countries together with the suspension of all US refugee programmes for 120 days. This executive order swiftly led to travellers, including pre-approved students, workers, refugees and green-card holders from Muslim-majority nations, being stranded at major airports and prevented from boarding flights to the US (Walters et al. 2017). The United Nations Commissioner for Human Rights emphasised that the ban was a waste of "resources needed for proper counter-terrorism", further indicating that "discrimination on nationality alone is forbidden under human rights law" (Withnall 2017). The ban was lifted on $3^{\text {rd }}$ February 2017 on the grounds of being unconstitutional. The executive order did not adhere to due process (protected by the Fifth Amendment) in which there must be "notice and a hearing prior to restricting an individual's ability to travel", while also constituting a violation of religious freedoms enshrined in the First Amendment (Economist 2017a). Nevertheless, despite significant public and legal opposition the US Supreme Court largely approved the revised ban proposal in June 2017, which came into effect thereafter (Laughland 2017).

Targeted campaigns against specific ethnic and religious groups are further inflamed through various media by organised networks of right-wing ideologues (Lean 2012). These publically manufactured anxieties play on and accentuate fears of a 'Muslim takeover', 
spatialized through the sardonic construction of such destinations as 'Eurabia', 'United States of Islamica' and 'Londonistan'. This further legitimises restrictions on Arab-Muslim tourism mobilities despite the fact Middle Eastern tourists visiting the US spend an average of US\$6,000 per capita, around US\$2,000 more than do European tourists (Hyde 2016). People's ethnic and/or racial makeup arguably determines access to states which espouse human rights and democratic freedoms while simultaneously discriminating against the mobility of those deemed 'irregular' or 'illegitimate'.

\section{Tourism, bordering and resort securitization}

The tightening of border security and widespread introduction of discrete and pervasive technologies of surveillance, increased in response to terror threats, have not only been directed at the hardening of border controls but in driving forward the securitization of hotels and resort infrastructures (Becklake 2019). Tourism is often implicated in multiple intersecting struggles for environmental, spatial and socioeconomic justice as it becomes imbricated in state-led strategies of resource enclosure and place resignification for the purpose of transforming space into tourism commodities or resorts (Devine 2017). The enclosure of resources and remaking of the public realm for tourism consumption do not merely reflect discriminatory bordering discourses but are implicated in the very bordering practices enacted by states to filter and segregate the movements of those deemed lacking the right credentials for travel. Hence, for example, the presence of refugees and undocumented migrants in prominent public spaces and places of leisure periodically triggers repressive interventions by the state to remove those deemed by the media to be interlopers in hospitable spaces (García Gallo 2015; Mail Online 2015). That said, there have also been instances where tourists and tourism establishments have demonstrated acts of compassion and solidarity towards vulnerable communities of migrants and refugees on the island of Kos (McVeigh 2015), as well as periodic displays of solidarity by airline passengers towards asylum seekers facing forced deportations (see Doherty 2015).

Moves to fortify and protect tourism installations have been defended as a response to the increased threat of terror attacks on major resorts and destinations. Such moves have also been driven by corporate concerns regarding the impact of repeated attacks on the profitability of the tourism industry (Lisle 2013, 137-8). Beyond the legitimate need to provide for the safety and security of tourists in resort settings there lie a deeper set of dynamics in which the securitization of tourism aligns with militarized bordering practices and the attendant forces of 
enclosure associated with "sharply expanded modes of profit extraction", depriving the world's poor of access to resources while reinforcing the carceral logics of the emerging global order (Sassen 2014, 18). The intersection of transnational capital flows, tourism mobilities and securitized bordering is demonstrated in the proliferation of cross-border zones in which uneven and differentiated mobilities underpin the political economy of tourism real state and resort development.

The 'Indonesia-Malaysia-Singapore Growth Triangle' (IMS-GT), established in 1990, combines Singaporean and Indonesian capital with cheap, predominantly Indonesian labour, in a capital-intensive fortified resort enclave, Bintan Beach Resorts International (BBIR); which is located on the north shore of Pulau Bintan in the Riau Islands (see Hampton 2010). Contrary to the project's promise of creating a seamless transnational space of mobility, the IMS-GT intensifies the "geo-economic" disparities between participating states at different levels of economic development, accentuating the mobility of capital and tourists while simultaneously regulating and controlling the selective entrance of migrants and workers (Revelli 2016). Following both the Asian Financial Crisis in the late 1990s and the 9/11 terrorist attacks, tougher border checks resulted in lengthy queues and increased cross-examination of Indonesians wishing to enter Singapore. Additionally, securitized entry-points designed "to keep locals out" have hindered the rights of Indonesian workers and tourists to feely enter the fortified BBIR resort enclave (Ford \& Lyons 2006, 21).

The growth of the fortified BBIR resort enclave and others throughout the Caribbean and South-East Asia, indicates the degree to which processes of capital accumulation and sociospatial practices linked to tourism have become intrinsic to the 'structural violence' inherent in bordering practices (Jones 2016, 8). Structural violence can be defined as the "more subtle forms of coercion that sustain relations of domination and exploitation, including the threat of violence" that underpin "the smooth functioning of our economic and political systems" (Zizek $2009,1)$. As the example of Bintan Island indicates, structural violence is manifest in tourism development through the interplay of forces through which territories are enclosed and resources privatized to ensure the continued accumulation of capital and profitability of tourism enterprises (see Büscher \& Fletcher 2017). Meanwhile, the relative freedom of movement and rights to enter certain spaces are governed and mediated by peoples' ethnic, national, religious, gendered, sexual, and class identities. Border-crossings are furthermore inscribed with moral 
values as tourists' movements "collide with contradictory ethno-national and territorial claims" (Rowen 2016, 388).

\section{Conclusions}

Irrespective of moves to liberalize cross-border formalities and introduce multilateral mobility arrangements in certain parts of the world during the 1990s, Ohmae's (1990) vision of a "borderless world" bears little resemblance to a world increasingly shaped by resurgent nationalisms, geopolitical realignments and the proliferation of restrictive bordering practices. The emerging global order is characterised by the increased pervasiveness and severity of (re)bordering practices in which differential mobility rights are becoming more marked and borders less porous, reaffirming Mau's $(2010,344)$ contention that "borders are rarely open or closed per se, but only with regards to specific persons and types of mobility".

Increasingly militarized borders underpinned by biometrics and technologies of surveillance are emblematic of a mobility crisis that is intrinsic to the production and reproduction of global capitalism of which tourism is an integral part. Multi-scalar bordering practices and persistent narratives of fear together with the mass consumption of personalised technologies further reinforce the complicity of mobile subjects in draconian border governance regimes. This 'biopolitical' order of global security increasingly undermines the universality of rights and erodes the civic bonds of trust that underpin secure social orders, democracy, solidarity with strangers and citizenship itself.

While the surpassing of one billion tourist arrivals has been widely celebrated governments appeared more determined to reassert their sovereignty and impose tougher border controls to restrict the movements of those deemed to lack the necessary credentials for travel. Moreover, framing tourism as a human right obscures a critical ethico-legal distinction between a democratic and universal politics of mobility and an activity enjoyed by a minority of the world's inhabitants. Such rights are framed by an authoritarian neoliberal logic upholding corporate freedoms to profit from tourist mobilities while restricting the mobility rights of workers and other disempowered subjects. This also masks the degree to which tourism is implicated in the production and reproduction of securitized bordering practices and associated patterns of resource enclosure and profit-making. This extends to the widespread exploitation 
of migrant labour and strategic manipulation of global hierarchies of uneven mobility to ensure flows of cheap, pliant labour into tourism and hospitality labour markets.

Tourism scholars cannot afford to ignore the deeper connections between the processes of bordering, securitization and resource enclosure that are integral to predatory forms of globalised capitalism and wider struggles for mobility justice. To do so will only serve to differentiate even further the rights enjoyed by tourists from those less fortunate, while further eroding the potential scope for advancing democratic and universal rights to the freedom of movement and travel for all.

\section{References}

Addley, E. \& Holpuch, A. (2015 December 22). US stops British Muslim family from boarding flight to visit Disneyland. Guardian. Retrieved November 16, 2017 from https://www.theguardian.com/us-news/2015/dec/22/us-stops-british-muslim-family-flightdisneyland-david-cameron.

Adey, P. (2006). If mobility is everything then it is nothing: Towards a relational politics of (im)mobilities. Mobilities, 1(1), 75-94.

African Development Bank (2016). The Africa visa openness report. Abidjan, Côte d'Ivoire: African Development Bank.

Ali, R. (2017, October 23). The anxieties of a Muslim traveller. Skift. Retrieved 30 November 2018, from https://skift.com/2017/10/23/the-anxieties-of-a-muslim-traveler/.

Amoore, L. (2006). Biometric borders: Governing mobilities in the war on terror. Political Geography, 25(3), 336-251.

Anderson, B. (2014). Exclusion, failure and the politics of citizenship. RCIS Working Paper, No. 2014/1. Toronto: Ryerson University.

Andreas, P. (2000). Introduction: The wall after the wall. In Andreas, P. and Snyder, T. (eds.) The Wall around the West. London: Rowman \& Littlefield.

Baerenholdt, J. O. (2013). Governmobility: the powers of mobility. Mobilities, 8(1), 20-34. Bauder, H. (2012-13). Open borders: A utopia? Justice Spatiale/Spatial Justice, 5, Dec 2012Dec 2013, 1-10. Retrieved July 24, 2017 from http://www.jssj.org.

Becklake, S. (2019). 'Touristic Security': Interrogating an emerging security practice. In

Cañada, E. (Ed.). Tourism in the Geopolitics of the Mediterranean (pp. 76-81). Barcelona: Alba Sud.

Bianchi, R.V. \& Stephenson, M.L. (2013). Deciphering tourism and citizenship in a globalized world. Tourism Management, 39, 10-20.

Bianchi, R.V. \& Stephenson, M.L. (2014). Tourism and Citizenship: Rights, freedoms and responsibilities in the global order. London: Routledge.

Blasco, D., Guia J. \& Prats, L. (2014). Emergence of governance in cross-border destinations. Annals of Tourism Research, 49, 159-173.

Breakey, N. \& Breakey, H. (2013). Is there a right to tourism? Tourism Analysis, 18, 739748.

Burrell, K. (2008). Materialising the Border: Spaces of Mobility and Material Culture in Migration from Post-Socialist Poland, Mobilities, 3(3), 353-373. 
Büscher, B. \& Fletcher, R. (2017). Destructive creation: capital accumulation and the structural violence of tourism. Journal of Sustainable Tourism, 25(5), 651-667.

Butcher, J. (2017). Citizenship, global citizenship and volunteer tourism: A critical analysis. Tourism, Recreation Research, 42(2), 129-138.

Butcher, J. \& Smith, P. (2019). Travel for the millions. Spiked. 25 September, Retrieved 29 November 2019 from https://www.spiked-online.com/2019/09/25/travel-for-the-millions/. Calori, A. (2015 February 17). From Mare Nostrum to Triton, Europe's response to the Mediterranean crisis is little more than another budget cut. Open Democracy. Retrieved 12 October 12, 2015 from https://www.opendemocracy.net/can-europe-make-it /annacalori/from-mare-nostrum-to-triton-europe $\%$ E2\% 80\%99s-response-to-mediterranean-crisis. Coles, T. \& Hall, C.M. (2011). Rights and regulation of travel and tourism mobility. Journal of Policy Research in Tourism, Leisure and Events, 3, 209-223.

Council of the European Union (2016 April 21). Council adopts EU Passenger Name Record (PNR) directive. Retrieved at October 9, 2017 from http://www. consilium.europa.eu/en/press/press-releases/2016/04/21-council- adopts-eu-pnr-directive/. Cresswell, T. (2013). Citizenship in worlds of mobility. In O. Soderstrom, D. Ruedin, S. Randeria, G. D'Amato \& F. Panese (Eds.), Critical mobilities (pp.105-124). London: Routledge.

Davis, G. (1961). My country is the world. New York: GB Putnam \& Sons.

Delanty, G. (2000). Citizenship in a global age: Society, culture and politics. Buckingham: Open University Press.

Delle Femmine, L. (2017 August 14). The lucrative business of securing Europe's borders. El País. Retrieved 23 November, 2017 from https://elpais.com/elpais/2017/08/08/inenglish/1502192834_823925.html?rel=lom (23 November 2017).

Devine, J. A. (2017). Colonizing space and commodifying place: tourism's violent geographies, Journal of Sustainable Tourism, 25, 5: 634-650.

Dheghan, S. K. (2017 July 21). Acclaimed Iranian artist refused visa to attend Edinburgh book festival. The Guardian. Retrieved 21 July, 2017 from

https://www.theguardian.com/world /2017/jul/21/acclaimed-iranian-artist-refused-visa-toattend-edinburgh-book-festival (21 July 2017).

Doherty, B. (2015 February 2). Passenger protest on Qantas flight delays forced transfer of Tamil asylum seeker. The Guardian, 2 February. Retrieved 4 December, 2015 from http://www.theguardian.com/australia-news/2015/feb/02/passenger-protest-on-qantas-flightdelays-transfer-tamil-asylum-seeker.

Doumayru, V. (2010). Antwerp's ring cycle. Le Monde Diplomatique, May, pp. 14-15. Dowty, A. (1987). Closed borders: The contemporary assault on the freedom of movement. New Haven and London: Yale University Press.

Dykins, R. (2016). Shaping the future of luxury travel: future traveller tribes 2030. Madrid: Amadeus AIT Group. Retrieved 9 October, 2017 from

http://www.amadeus.com/documents/future-traveller-tribes-2030/luxury-travel/shaping-thefuture-of-luxury-travel-report.pdf.

Eaton, G. (2017). The case for open global borders. New Statesman, 18-24 August, p. 17. Economist (2017b May 4). How much do sanctuary cities stand to lose? Economist.

Retrieved 18 November, 2017 from https://www.economist.com/news/united states/21721655-probably-not-much-they-are-jittery-all-same-how-much-do-sanctuary-citiesstand.

Engelhardt, T. (2015). We didn't ordain this constitution. Le Monde Diplomatique, April, 67. Retrieved 24 March, 2017 from https://mondediplo.com/2015/04/11usa 
Enloe, C. (2014). Bananas, Beaches and Bases: making feminist sense of international politics. Berkeley: University of California Press.

Evening Standard (2011 June 30). Unions have jumped the gun, claims minister. Evening Standard, p.1/5.

Faist, T. (2009). The transnational social question: social rights and citizenship in a global context. International Sociology, 24(1), 7-35.

Favell, A. (2001). Migration, mobility and globaloney. Metaphors and rhetoric in the sociology of globalization. Global Networks, 1(4), 389-98

Ferguson, L. (2007). The United Nations World Tourism Organisation. New Political Economy, 12(4), 557-568.

Fernández Rubio, A. (2015 April 22). Turismo, la industria que mueve el mundo. El País. Retrieved 5 August, 2017 at https://elpais.com/elpais/2015/04/20/eps/142954 8597_667553.html.

Ford, M.T. \& Lyons, L.T. (2006). The borders within: mobility and enclosure in the Riau islands. Asia Pacific Viewpoint, 47(2), 257-271.

Foucault, M. (1978). The history of sexuality, vol. 1 (trans. Robert Hurley). New York: Vintage.

Franquesa, J. (2011). 'We've lost our bearings': Place, tourism and the limits of the 'mobility turn'. Antipode, 43(4), 1012-1033.

Fregonese, S. \& A. Ramadan (2015) Hotel geopolitics: A research agenda. Geopolitics, 20: 793-813.

García Gallo, G. (2015). Aguirre quiere sacar a los 'sin hogar' de la calle para impulsar el turismo. El País, 25 April. Retrieved at

https://elpais.com/ccaa/2015/04/27/madrid/1430144657 879791.html, (6 December 2015). Gascón, J. (2019). Tourism as a right: "frivolous claim" against degrowth? Journal of Sustainable Tourism, 27(12): 1825-1838.

Geddes, A. (2000). Immigration and European Integration: Towards Fortress Europe? Manchester: Manchester University Press.

Gillen, J. \& M. Mostafanezhad (2019) Geopolitical encounters of tourism: a conceptual approach. Annals of Tourism Research, 75: 70-78.

Government of Timor-Leste (2015). European Parliament approves visa arrangement with Timor-Leste, Government of Timor-Leste. Retrieved 23 January, 2017 at http://timorleste.gov.tl/?p=14220\&lang=en (23 January 2017).

Guardian (2015 January 9). Marine Le Pen calls for tighter borders following Charlie Hebdo attack. The Guardian. Retrieved 8 August 2016 from

https://www.theguardian.com/world/video/2015/jan/09/marine-le-pen-calls-tighter-bordersfollowing-charlie-hebdo-attack-video

Guereno-Omil, B., Hannam, K., Alzua-Sorzabal, A. (2014). Cross-border leisure mobility in the Basque Euro-City. Leisure Studies, 33(6), 547-564.

Hampton, M. (2010). Enclaves and ethnic ties: The local impacts of Singaporean crossborder tourism in Malaysia and Indonesia. Singapore Journal of Tropical Geography, 31, 239-253.

Hannam, K. (2013). "Shangri-La and the new "great game": Exploring tourism geopolitics between China and India. Tourism Development and Planning, 10(2), 176-186.

Hannam, K., M. Sheller \& J. Urry (2006). Editorial: Mobilities, immobilities and moorings. Mobilities 1(1), 1-22.

Hardy, J. (2000). The uninvited: refugees at the rich man's gate. London: Profile Books. Hazbun, W. (2008) Beaches, ruins, resorts: the politics of tourism in the Arab world. Minneapolis / London: University of Minnesota Press. 
Henley \& Partners (2015). Visa restriction index. Retrieved 7 November, 2016 from https://www.henley.global.com/files/download/HP/hvri/HP\%20Visa\%20Restrictions\%20Ind ex\%20151001.pdf

Henley \& Partners (2016). Visa restriction index: Global travel freedom at a glance.

Retrieved 7 November 2016 from https://www.henleyglobal.com/files/download

/HP/hvri/HP\%20Visa\%20Restrictions\%20Index\%20160223.pdf.

Hickman, M., Thomas, L., Silvestri, S. \& Nickels, H. (2011). Suspect communities? Counterterrorism policy, the press, and the impact on Irish and Muslim communities in Britain.

London: London Metropolitan University.

Higgins-Desbiolles, F. (2007). Hostile meeting grounds: encounters between the wretched of the earth and the tourist through tourism and terrorism in the 21 st century. In P. Burns \& M. Novelli (Eds.) Tourism and politics: global frameworks and local realities (pp. 309-332), Oxford: Elsevier.

Hirst, P. and G. Thompson (1996). Globalization in question. Cambridge: Polity Press Hyde, R. (2016 January 13). The economic impact of banning Muslims from the US. Investopedia. Retrieved 6 March, 2017 from

http://www.investopedia.com/articles/investing/011316/economic-impact-banning-muslimsus.asp.

International Organization for Migration (2017 June 1). Mediterranean migrant arrivals top 363,348 in 2016; deaths at sea: 5,079. Retrieved 24 July, 2017 from

https://www.iom.int/news/mediterranean-migrant-arrivals-top-363348-2016-deaths-sea-5079. Jones, R. (2016). Violent borders: refugees and the right to move. London: Verso.

Kassabova, K. (2017). Border: A journey to the edge of Europe. London: Granta.

Kaur, R. \& Hutnyk, J. (1999). Introduction. In R. Kaur \& J. Hutnyk (Eds.) Travel worlds: Journeys in contemporary cultural politics (pp.1-13), London: Zed Books.

Khan, M. (2016, 9 March). Two Muslim women were taken off JetBlue flight for filming the safety briefing, Business Insider. Retrieved 5 August, 2016 from

http://www.businessinsider.com/muslim-women-kicked-off-jetblue-flight-2016-3.

Kingsley, P. (2016 March 18). Refugee crisis: what does the EU's deal with Turkey mean?

The Guardian. Retrieved 12 October, 2017 from https://www.theguardian.com/world/2016/ mar/18/eu-deal-turkey-migrants-refugees-q-and-a

Labour \& European Law Review (2008 May 15). Summaries of Viking and Laval, Weekly Issue 66. Retrieved 20 November, 2017 from

https://www.thompsonstradeunion.law/news/lelr/weekly-issue-66/summaries-of-viking-andlaval.

Laughland, O. (2017 June 27). Trump travel ban: US supreme court partially lifts block on order. The Guardian. Retrieved 20 November, 2017 from https://www.the guardian.com/usnews/2017/jun/26/trump-travel-ban-supreme-court-block-partially-lifted.

Lean, N. (2012). The Islamophobia industry: How the right manufacturers fear of Muslims. London: Pluto Press.

Lisle, D. (2013). Frontline leisure: securitizing tourism in the war on terror. Security

Dialogue, 44, 127-146.

Lloyd, D. (2003). The passport: The history of man's most travelled document. Stroud:

Sutton Publishing.

Lyon, D. (2004). Surveillance after September 11. Cambridge: Polity.

Mail Online (2015 May 27). How many more can Kos take? Mail Online. Retrieved 7

December, 2015 from http://www.dailymail.co.uk/news/article-309973/Holidays-misery-

boat-people-Syria-Afghanistan-seeking-asylum-set-migrant-camp-turn-popular-Greek-island-

Kos-disgusting-hellhole.html 
Mau, S. (2010). Mobility citizenship, inequality, and the liberal state: the case of visa policies. International Political Sociology, 4, 339-61.

McKinstry, L. (2017 August 3). New border rules are just EU's bid to punish Britain. Retrieved 7 August, 2017 from http://www.express.co.uk/comment/columnists/leomckinstry/836323/eu-airport-border-queues-security-britain-holiday-tourists.

McVeigh, T. (2015b June 6). Sympathy and solidarity for migrants on Kos beaches as two worlds collide. The Guardian. Retrieved 14 June, 2015 from https://www.theguardian. com/world/2015/jun/06/kos-migrants-tourists-greece-traffickers-sympathy solidarity?CMP=share btn_fb\#img-2

Moore, P. V. (2012). Where is decent work in DfID policy? Marketisation and securitisation of UK international aid. Global Labour Column. Retrieved 7 January, 2013 from http://column-labour-university.org/2013/01/where-is-decent-work-in-dfid-policy.html. National, The (2016 September 4). UAE eases visas for Chinese visitors. The National. Retrieved 22 January, 2017 from http://www.thenational.ae/uae/uae-eases-visas-for-chinesevisitors.

Nkyi, E. \& Hashimoto, A. (2015). Human rights issues in tourism development. In R. Sharpley \& D. J. Telfer (Eds.) Tourism and development: Concepts and issues (pp. 378-399), $2^{\text {nd }}$ Edition. Bristol: Channel View Publications.

Ohmae, K. (1990). The borderless world. London: Collins.

Oltermann (2014 September 11). UK may allow US security checks on passengers before transatlantic travel, The Guardian. Retrieved 12 October 2015 from https://www.theguardian.com/uk-news/2014/sep/11/uk-us-security-checks-passengers. Ó Tuathail, G. (1999). Borderless worlds? Problematising discourses of deterritorialisation. Geopolitics, 4(2), 139-154.

Peltier, D. (2015 October 13). 7 charts highlighting the spending power of Chinese travelers, Skift. Retrieved 6 October, 2017 from https://skift.com/2015/10/13/7-charts-highlighting-thespending-power-of-chinese-travelers/.

Powles, J. (2015 March 11). We are citizens, not merely physical masses of data for harvesting. The Guardian. Retrieved 16 November, 2015 at http://www.theguardian.com/technology/2015/mar/11/we-are-citizens-not-mere-physicalmasses-of-data-for-harvesting.

Prince, R. (2010 January 10). David Cameron: net immigration will be capped at tens of Thousands. The Telegraph. Retrieved 24 July, 2017 at

http://www.telegraph.co.uk/news/politics/6961675/David-Cameron-net-immigration-will-becapped-at-tens-of-thousands.html (24 July 2017).

Prokkola, E-K (2012). Neoliberalizing border management in Finland and Schengen.

Antipode, 45(5), 1318-1336.

Reuters (2015 August 29). Chris Christie proposes tracking immigrants the way FedEx tracks packages. New York Times. Retrieved 16 November, 2015 at

http://www.nytimes.com/2015/08/30/us/politics/christie- proposes-immigrant-tracker-similarto-fedex.html.

Revelli, P. (2016 August). Singapore's golden triangle. Le Monde Diplomatique, pp. 8-9. Richardson, T. (2013). Borders and Mobilities: Introduction to the Special Issue. Mobilities, 8(1), 1-6.

Robin, M. (2017 August). In Arizona, Tump's border already exists. Le Monde Diplomatique, pp. 2-3.

Rowen, I. (2016). The geopolitics of tourism: Mobilities, territory and protest in China, Taiwan and Hong Kong. Annals of the Association of Geographers, 106(2), 385-393. Rowen, I. (2014) Tourism as a territorial strategy: The case of China and Taiwan. Annals of Tourism Research, 46: 62-74. 
Rumford, C. (2006). Theorizing borders. European Journal of Social Theory, 9(2), 155-169. Salazar, N. \& Schiller, N. G. (2013). Regimes of mobility across the globe. Journal of Ethnic and Migration Studies, 39(2), 183-200

Salter, M. B. (2006). The global visa regime and the political technologies of the international self: borders, bodies, biopolitics, Alternatives: Global, Local, Political, 31(2), 167-89.

Sassen, S. (2014). Explusions: Brutality and complexity in the global economy. Cambridge, MA: Belknapp Press (Harvard University Press).

Scuzzarello, S. \& Kinnvall, C. (2013). Rebordering France and Denmark Narratives and Practices of Border-Construction in Two European Countries, Mobilities, 8(1), 90-106.

Serhan, (2017 July 7) Will France's state of emergency become permanent? The Atlantic, 7 July. Retrieved 7 August 2017 from

https://www.theatlantic.com/international/archive/2017/07/will-frances-state-of-emergencybecome-permanent/532848/.

Sheller, M. (2010). Air mobilities on the US-Caribbean border: Open skies and closed gates. The Communication Review, 13: 269-288.

Sheller, M. (2018) Mobility justice: The politics of movement in an age of extremes. London: Verso.

Statewatch (2015). Observatory bookmark and share EU-PNR (Passenger Name

Record):2011 ongoing. Updated: 27.7.15. Retrieved 8 August, 2017 from

http://www.statewatch.org/Targeted-issues/eu-pnr/eu-pnr-observatory.htm.

Steiner, R. (2017 August 6). Trailfinders blames Brexit vote for wiping out $£ 12 \mathrm{~m}$ profit. The Guardian. Retrieved 20 November, 2017 from

https://www.theguardian.com/business/2017/aug/06/trailfinders-blames-brexit-vote-for-

wiping-out-12m-profit.

Stephenson, M. L. (2006). Travel and the freedom of movement: racialised encounters and experiences amongst ethnic minority tourists in the EU. Mobilities 1(2): 285-306.

Telfer, D. J. \& Hashimoto, A. (2015). Tourism, development and international studies. In R. Sharpley \& D. J. Telfer (Eds.) Tourism and development: Concepts and issues (pp. 400-417), $2^{\text {nd }}$ Edition. Bristol: Channel View Publications.

Tesfahuney, M. (1998). Mobility, racism, geopolitics. Political Geography, 17(5), 499-515.

Therborn, G. (2017). Dynamics of inequality, New Left Review, 103, 67-85.

Timothy, D. J. (2001). Tourism and political boundaries. London: Routledge.

Timothy, D. J. (2000) Borderlands: an unlikely tourist destination? IBRU Boundary and Security Bulletin, 8(1), 57-65.

Ting, D. (2017 June 5). Hotel CEOs push back against Trump on travel ban, brand USA and Cuba, Skift. Retrieved 24 July, 2017 from https://skift.com/2017/06/05/hotel-ceos-push-backagainst-trump-on-travel-ban-brand-usa-and-cuba/

Torabian, P. \& Miller, M. C. (2017). Freedom of movement for all? Unpacking racialized travel experiences. Current Issues in Tourism, 20(9), 931-945.

Torpey, J. (2000). The invention of the passport: Surveillance citizenship and the state.

Cambridge: Cambridge University Press.

United Nations (1948). Universal Declaration of Human Rights. New York: United Nations.

Retrieved 19 December, 2007 from http://www.un.org/Overview/rights.html.

UNWTO (United Nations World Tourism Organization) (1999). Global Code of Ethics for

Tourism, Madrid: UNWTO. Retrieved 29, December 2012 from

http://www.unwto.org/ethics/full_text/en/pdf/Codigo_Etico_Ing.pdf.

UNWTO (2019). Tourism: A global force for growth and development - UNWTO Executive Council meets in Baku. Retrieved 29 November 2019 from http://www2.unwto.org/pressrelease/2019-06-18/tourism-global-force-growth-and-development-unwto-executive-councilmeets-b. 
UNWTO (2017). Framework Convention on Tourism Ethics. Retrieved 23 November 2017 from http://ethicsconventions.unwto.org/.

Urry, J. (2013). Societies beyond oil: Oil dregs and social futures. London: Zed Books.

Vallet, E. \& C-P. David (2012). Introduction: The (re)building of the wall in international relations, Journal of Borderlands Studies, 27(2): 111-119.

Vaughn-Williams, N. (2012). Border politics: The limits of sovereign power. Edinburgh:

Edinburgh University Press.

Verkaik, R. (2007 October 8). Major airline refuses to help with forcible removal of immigrants. The Independent. Retrieved 24 October, 2001 from

http://www.independent.co.uk/news/uk/crime/major-airline-refuses-to-help-with-forcibleremoval-of-immigrants-394451.html.

Walters, W. (2006). Border/control. European Journal of Social Theory, (92), 187-203.

Walters, J., Helmore, E. \& Dehghan, S.K. (2017 January 28). US airports on frontline as Donald Trump's travel ban causes chaos and protests. Guardian. Retrieved 11 October 2017 from https://www.theguardian.com/us-news/2017/jan/28/airports-us-immigration-banmuslim-countries-trump.

Watt, N. (2013 October 13). George Osborne opens the doors to rich Chinese with new visas system. BBC News. Retrieved 4 November, 2013 from

https://www.theguardian.com/politics/2013/oct/14/george-osborne-china-visa.

Weaver, A. (2008). When tourists become data: consumption surveillance and commerce.

Current Issues in Tourism, 11(1), 1-23.

Withnall, A., (2017 January 30). UN denounces Trump's travel ban as 'mean-spirited' and illegal under human rights law. Retrieved 1 February, 2017 from

http://www.independent.co.uk/news/world/americas/donald-trump-muslim-travel-ban-illegalun-rights-chief-a7552991.html.

WTO (1980) Manila Declaration on Tourism. Madrid: World Tourism Organisation. WTO (1999). Global Code of Ethics for Tourism. Madrid: World Tourism Organisation. WTTC (World Travel and Tourism Council) (2017). Closing borders, risking jobs World Travel \& Tourism Council warns US Administration. 5 February 2017. Retrieved from https://www.wttc.org/media-centre/press-releases/press-releases/2017/closing-borders-risksjobs-world-travel-and-tourism-council-warns-us-administration/, (30 July 2017).

Zizek, S. (2009). Violence. London: Profile Books.

\footnotetext{
${ }^{1}$ In 2016 refugee and migrant arrivals via the Mediterranean peaked at 363,348. In addition there were an estimated 5,079 fatalities and missing persons (International Organization for Migration, 2017)

${ }^{2}$ In the United States the Department of Homeland Security, the federal agency encharged with protecting US national security and securing its borders, is in fact part of a complex web of private companies, lobbyists and bureaucrats (Engelhardt, 2015, p.7).
} 